6. Бугайчук К.Л., Федосова О.В. Проникнення до житла чи іншого володіння особи в частині дотримання прав i свобод людини і громадянина (стаття 38 Закону України «Про Національну поліцію»): наук.-практ. рекомендації / Харків : Харк. нац. ун-т внутр. справ, 2019. $60 \mathrm{c}$.

7. Маляренко В.Т. Про недоторканність житла та іншого володіння особи як засаду кримінального судочинства // Верховний суд України. URL: http://www.viaduk.net/clients/vsu/vsu.nsf/(print)/75488B020FF6EC4 6C2257AF4003AE4E0 (дата звернення: 15.04.2021).

8. Ташматов В.А. Проникнення до житла чи іншого володіння особи як превентивний поліцейський захід. Південноукраӥнський правничий часопис. 2016. № 1. С. 108-112.

DOI https://doi.org/10.30525/978-9934-26-074-2-53

\title{
ГРУПА ОСІБ ЯК ОСОБЛИВО КВАЛІФІКУЮЧА ОЗНАКА КРИМІНАЛЬНИХ ПРАВОПОРУШЕНЬ ПРОТИ СТАТЕВОЇ СВОБОДИ ТА СТАТЕВОЇ НЕДОТОРКАННОСТІ ОСОБИ
}

\author{
Митрофанова Ю. С. \\ старший викладач кафедри кримінального права та кримінології \\ факультету № 6 \\ Харківського начіонального університету внутрішніх справ \\ м. Харків, Украӥна
}

Відповідно до ч. 1 ст. 28 Кримінального кодексу України (далі - КК) кримінальне правопорушення визнається таким, що вчинене групою осіб, якщо у ньому брали участь декілька (два або більше) виконавців без попередньої змови між собою [1]. Згідно ч. 2 ст. 27 КК виконавцем (співвиконавцем) $є$ особа, яка у співучасті з іншими суб'єктами кримінального правопорушення безпосередньо чи шляхом використання інших осіб, що відповідно до закону не підлягають кримінальній відповідальності за скоєне, вчинила кримінальне правопорушення, передбачене цим Кодексом. В науці кримінального права наголошується, що виконавцем (співвиконавцем) є особа, яка безпосередньо виконує діяння, що утворюють повністю чи частково об'єктивну сторону складу злочину [2, с. 186]. Отже, за змістом ч. 1 ст. 28 КК та ч. 2 ст. 27 КК кримінальне правопорушення може визнаватися вчиненим групою осіб, коли його вчиняють два співучасники як співвиконавці. Ознаками 
групи осіб є: 1) участь у ній як співвиконавців не менш як двох суб'єктів; 2) безпосередня участь іiї співвиконавців у вчиненні хоча б однісї дії, що утворюють повністю чи частково об'єктивну сторону складу кримінального правопорушення.

Однією з особливо кваліфікуючих ознак згвалтування (ч. 3 ст. 152 КК) та сексуального насильства (ч. 3 ст. 153 КК) є вчинення зазначених кримінальних правопорушень групою осіб. В науці кримінального права зазначається, що згвалтування та сексуальне насильство вчинені групою осіб вважаються, якщо у них брали участь декілька (два або більше) виконавців (співвиконавців), тобто співучасників, ознаки яких зазначено у частині 2 ст. 27 КК, при цьому виконавці (співвиконавці) діють узгоджено, $з$ єдиним умислом, і кожен з них безпосередньо виконує діяння, що утворюють повністю чи частково об'єктивну сторону складу злочину [3, с. 144, 149]. Для інкримінування цієї кваліфікуючої ознаки не вимагається попередня змова між учасниками злочину; узгодженість дій співвиконавців може виникнути безпосередньо в процесі згвалтування [4, с. 51-52].

Слід вказати, що попередня редакція ст. 152 КК «Згвалтування» встановлювала кримінальну відповідальність за статеві зносини із застосуванням фізичного насильства, погрози його застосування або 3 використанням безпорадного стану потерпілої особи. Попередня редакція ст. 153 КК мала назву «Насильницьке задоволення статевої пристрасті неприроднім способом» та встановлювала кримінальну відповідальність за задоволення статевої пристрасті неприродним способом із застосуванням фізичного насильства, погрози його застосування або з використанням безпорадного стану потерпілої особи. Ці злочини (ч. 3 ст. 152 КК та ч. 2 ст. 153 КК) передбачали однією 3 кваліфікуючих ознак «вчинення групою осіб». В науковій літературі щодо такої кваліфікуючої ознаки як «вчинене групою осіб» (в попередніх редакціях ст. 152 КК та ст. 153 КК) зазначалося, що згвалтування вчинене групою осіб, має місце тоді, коли група 3 двох або більше осібспіввиконавців діє узгоджено з метою вчинення статевих зносин 3 однією або кількома потерпілими особами. Узгодженість дій передбачає усвідомленість кожним учасником групи того, що його поведінка сприяє спільному вчиненню згвалтування [5, с. 191, 205].

У п. 9 Постанови Пленуму Верховного суду України «Про судову практику у справах про злочини проти статевої свободи та статевої недоторканості особи» від 30.05.2008 року № 5 зазначається, що злочин, передбачений ст. 152 чи ст. 153 КК, визнається вчиненим групою осіб, 
якщо у ньому брали участь декілька (два або більше) виконавців (співвиконавців), тобто співучасників, ознаки яких зазначені у ч. 2 ст. 27 КК. При цьому виконавці (співвиконавці) діють узгоджено, 3 єдиним умислом і кожен 3 них безпосередньо виконує діяння, що утворюють повністю чи частково об'єктивну сторону складу злочину. У разі, коли із групи осіб, які вчинили згвалтування або насильницьке задоволення статевої пристрасті неприродним способом, лише одна особа є суб'єктом злочину, а решта осіб внаслідок неосудності або у зв'язку з недосягненням віку, з якого може наставати кримінальна відповідальність, чи 3 інших підстав не можуть бути суб'єктами злочину, дії винної особи, яка за таких обставин притягується до кримінальної відповідальності, не можна розглядати як вчинення злочину групою осіб [6].

Таким чином, відповідно до попередніх редакцій ст. 152 КК та ст. 153 КК, згвалтування або насильницьке задоволення статевої пристрасті неприроднім способом вчинені групою осіб мали місце, якщо у них брали участь декілька (два або більше) виконавців (співвиконавців), тобто співучасників, ознаки яких зазначені у ч. 2 ст. 27 КК. При цьому виконавці (співвиконавці) діють узгоджено, 3 єдиним умислом і кожен 3 них безпосередньо виконує діяння, що утворюють повністю чи частково об'єктивну сторону складу злочину, тобто застосування фізичного насильства, погрози його використання та статеві зносини із потерпілою особою.

Чинні редакції ст. 152 та ст. 153 КК, передбачають іншу складову об’єктивної сторони складу кримінальних правопорушень. Так, згідно ч. 1 ст. 152 КК згвалтування - це вчинення дій сексуального характеру, пов'язаних iз вагінальним, анальним або оральним проникненням в тіло іншої особи з використанням геніталій або будь-якого іншого предмета, без добровільної згоди потерпілої особи. Згідно ч. 1. ст. 153 КК сексуальне насильство - це вчинення будь-яких насильницьких дій сексуального характеру, не пов'язаних із проникненням в тіло іншої особи, без добровільної згоди потерпілої особи. Отже, виконавцем (співвиконавцем) згвалтування $є$ особа, яка вчиняє дії сексуального характеру, пов'язані із вагінальним, анальним або оральним проникненням в тіло іншої особи з використанням геніталій або будь-якого іншого предмета, без добровільної згоди потерпілої особи. А виконавцем (співвиконавцем) сексуального насильства $\epsilon$ особа, яка вчиняє дії сексуального характеру, не пов'язані із проникненням в тіло іншої особи, без добровільної згоди потерпілої особи. Слід додати, що на думку О.О. Дудорова та М. І. Хавронюка, як співвиконавство згвалтування 
може розглядатись і поведінка того, хто не вчиняв і не мав наміру вчинити сексуальне проникнення в тіло потерпілої особи, але забезпечуючи недобровільність вказаного проникнення іншою особою, вчинив дії, які позбавили потерпілу особу можливості уникнути сексуального проникнення (зокрема, застосував до потерпілої особи насильство фізичне або психічне) тобто, співвиконавцем групового згвалтування може виступити і той, хто не здатен бути суб'єктом індивідуального згвалтування, - якщо цей злочин набуває вигляду гетеросексуального коїтусу за відсутності добровільної згоди (імпотент, жінка при згвалтуванні особи жіночої статі тощо) [7, с. 140]. На кваліфікацію згвалтування групою осіб як закінченого злочину для всіх співвиконавців не впливає те, чи вдалося кожному із гвалтівників здійснити сексуальне проникнення в тіло потерпілої особи [4, с. 43].

Таким чиним, підсумовуючі викладене слід зробити наступні висновки:

1) згвалтування або сексуальне насильство, вчинені групою осіб вважаються такими, якщо у їх вчиненні брали участь декілька (два або більше) співвиконавців, ознаки яких передбачені ч. 2 ст. 27 КК. При цьому співвиконавці діють узгоджено, 3 єдиним умислом, і кожен 3 них безпосередньо виконує діяння, що утворюють повністю або частково об'єктивну сторону складу кримінального правопорушення, передбаченого ст. 152 або ст. 153 КК.

2) група осіб відсутня, якщо декілька суб'єктів вчиняють дії, передбачені ст. 152 КК чи ст. 153 КК, однак не узгоджують при цьому свої дії і не сприяють один одному у їх вчинені.

\section{Література:}

1. Кримінальний кодекс України : Закон від 05.04.2001 № 2341-III // База даних (БД) «Законодавство України» / Верховна Рада (ВР) України. URL: https://zakon.rada.gov.ua/laws/-show/2341-14 (дата звернення: 18.04.2021).

2. Кваша О. О., Харко Д. М. Виконавець злочину у структурі співучасті : монографія. Київ : ПрАТ «Волинська обласна друкарня», 2015. $224 \mathrm{c}$.

3. Кримінальне право України. Особлива частина : навчальний посібник / А. А. Васильєв, О. О. Житний, С. О. Гладкова та ін.; за ред. О. М. Литвинова. Харків : Право, 2020.656 с.

4. Дудоров О.О. Злочини проти статевої свободи та статевої недоторканості особи (основні положення кримінально-правової 
характеристики) : практ. порадник / О.О. Дудоров; МВС України, Луган. держ. ун-т внутр. справ ім. Е.О. Дідоренка. Сєвєродонецьк : РВВ ЛДУВС ім. Е.О. Дідоренка, 2018. 92 с.

5. Кримінальне право (Особлива частина): підручник / за ред. О.О. Дудорова, Є.О. Письменського. Т.1. Луганськ: видавництво «Еталон-2». 2012. 780 с.

6. Про судову практику у справах про злочини проти статевої свободи та статевої недоторканості особи : Постанова Пленуму Верховного Суду України від 30.05.2008 № 5 // БД «Законодавство України» / BP України. URL: https://zakon.rada.gov.ua/laws/show/ v0005700-08\#Text (дата звернення: 18.04.2021р.).

7. Дудоров О.О., Хавронюк М.I. Відповідальність за домашнє насильство і насильство за ознакою статі (науково-практичний коментар новел Кримінального кодексу України) : за ред. М. І. Хавронюка. К.: Baiтe, 2019. 288 c.

DOI https://doi.org/10.30525/978-9934-26-074-2-54

\title{
ДО ПИТАННЯ ПРО СТРУКТУРУ, КОЕФІЦЕНТ ЗЛОЧИННОЇ ІНТЕНСИВНОСТІ, ХАРАКТЕР ТА ГЕОГРАФІЮ КРИМННАЛЬНИХ ПРАВОПОРУШЕНЬ ПРОТИ БЕЗПЕКИ РУХУ ТА ЕКСПЛУАТАЦІї ТРАНСПОРТУ В УКРАЇНІ
}

\author{
Новіков О. В. \\ кандидат юридичних наук,
}

асистент кафедри кримінології та кримінально-виконавчого права Національного юридичного університету імені Ярослава Мудрого, старший науковий співробітник відділу кримінологічних досліджень

Науково-дослідного інституту вивчення проблем злочинності імені академіка В. В. Сташиса Національної академії правових наук України м. Харків, Україна

Важливим етапом кримінологічного дослідження будь-якого різновиду злочинності $\epsilon$ аналіз іiі показників. Показники злочинності підлягають вимірюванню для отримання уявлення про іiі розміри, міру змінюваності, ймовірність та величину майбутнього прояву, а також для 